\title{
KARAKTERISTIK AYAH DALAM PARTISIPASI POSYANDU AYAH PEDULI DI DUSUN REJOAGUNG DESA REJOAGUNG KECAMATAN PLOSO KABUPATEN JOMBANG
}

\author{
Father Characteristics In Posyandu Participation Of Father's Care In Dusun \\ Rejoagung Desa Rejoagung Ploso Jombang District
}

\author{
Monika Sawitri Prihatini, Ririn Probowati, Heri Wibowo \\ STIKES Pemkab Jombang \\ Email: monika.sawitri@yahoo.co.id
}

\begin{abstract}
ABSTRAK
Dusun Rejoagung Desa Rejoagung Kecamatan Ploso Kabupaten Jombang terdapat Posyandu Ayah Peduli. Di posyandu ini tidak hanya perempuan yang menjadi pengunjung dan kader, tetapi ada peran lakilaki, baik sebagai kader dan pengantar balitanya. Tujuan penelitian ini adalah untuk menganalisis hubungan karakteristik ayah (tingkat pindidikan, tingkat pengetahuan, pekerjaan, usia, lama tinggal) dan dukungan keluarga dengan partisipasi ayah dalam Posyandu Ayah Peduli.

Jenis penelitian yang digunakan adalah analitik korelasional pendekatan cross sectional. Populasi adalah ayah yang memiliki anak balita di Dusun Rejoagung Desa Rejoagung Kecamatan Ploso Kabupaten Jombang sejumlah 60 ayah. Penelitian dilakukan bulan September 2017. Sampel penelitian ini adalah 53 ayah yang memiliki anak balita di Dusun Rejoagung Desa Rejoagung Kecamatan Ploso Kabupaten Jombang. Pengambilan sampel menggunakan metode probability sampling dengan teknik simple random sampling. Pengumpulan data menggunakan kuesioner dan buku absensi kehadiran posyandu. Analisis data dilakukan pengujian chi square.

Hasil analisis data nilai $\mathrm{p}=0,661$ artinya tidak ada hubungan antara tingkat pendidikan ayah dengan partisipasi ayah. Analisis data didapatkan nilai $\mathrm{p}=0,393$ artinya tidak ada hubungan antara tingkat penghasilan ayah dengan partisipasi ayah. Analisis data didapatkan nilai $\mathrm{p}=0,507$ artinya tidak ada hubungan antara pekerjaan ayah dengan partisipasi ayah. Analisis data didapatkan nilai $\mathrm{p}=0,980$ artinya tidak ada hubungan antara usia ayah dengan partisipasi ayah. Analisis data didapatkan nilai $\mathrm{p}=0,231$ artinya tidak ada hubungan antara lama tinggal ayah dengan partisipasi ayah. Hasil analisis data didapatkan nilai $\mathrm{p}=$ 0,680 artinya tidak ada hubungan antara dukungan keluarga dengan partisipasi ayah.

Keberhasilan posyandu tergantung dari peran serta masyarakat, diharapkan masyarakat tidak hanya ibu tetapi ayah ikut berpartisipasi terhadap program posyandu dan ayah harus ikut terlibat dalam pemantauan tumbuh kembang anak.
\end{abstract}

Kata kunci: karakteristik ayah, partisipasi, posyandu

Rejoagung Village Ploso District Jombang District Posyandu Ayah Peduli. In this posyandu not only women who become visitors and cadres, but there is the role of men, both as cadres and take her child. The purpose of this study was to analyze the relationship of father characteristics (education level, knowledge level, occupation, age, length of stay) and family support with the participation of father in Posyandu Ayah Peduli.

The type of research used is correlational analytic cross sectional approach. The population is a father who has children under five in Rejoagung Village Ploso District Jombang district of 60 fathers. The study was conducted in September 2017. The sample of this study is 53 fathers who have children under five in Rejoagung Village Ploso District Jombang. Sampling using probability sampling method with simple random sampling technique. Data collection using questionnaire and attendance book attendance posyandu. The data were analyzed by chi square test. 
The result of data analysis $\mathrm{p}$ value $=0,661$ means there is no relation between father education level with father participation. Data analysis got value $\mathrm{p}=0,393$ meaning there is no relation between father income level with father participation. Analysis of data obtained $\mathrm{p}$ value $=0.507$ means there is no relationship between the father's work with the participation of the father. Analysis of data obtained $\mathrm{p}$ value $=$ 0.980 means there is no relationship between father's age with the participation of father. Analysis of data obtained $\mathrm{p}$ value $=0.231$ means there is no relationship between the length of stay with the father's father participation. Result of data analysis got value $\mathrm{p}=0,680$ meaning there is no relation between family support with father participation.

The success of posyandu depends on the participation of the community, it is expected that the community is not only the mother but the father participates in the posyandu program and the father must be involved in monitoring the growth of the child.

Keywords: father characteristics, participation, posyandu

\section{PENDAHULUAN}

Salah satu pembangunan kesehatan yang akan ditempuh sampai tahun 2025 adalah semua rukun warga/lingkungan telah memiliki minimal satu posyandu aktif yang melaksanakan kegiatan minimum sebulan sekali (Depkes RI, 2009). Di Dusun Rejoagung Desa Rejoagung dan Dusun Sidopulo Desa Losari Kecamatan Ploso Kabupaten Jombang pada awal bulan Mei 2016 dibentuk Posyandu Ayah Peduli oleh Ketua PKK Kabupaten Jombang. Posyandu ini dibentuk sebagai bentuk kepedulian keterlibatan ayah dan kader laki-laki dan sebuah bentuk kerjasama yang baik antara ayah dan ibu sebagai orang tua didalam memantau tumbuh kembang anak. Akan tetapi, para ayah belum dapat memanfaatkan program posyandu ayah peduli ini dengan baik.

Studi pendahuluan yang dilakukan pada bulan Agustus 2017 di Dusun Rejoagung Desa Rejoagung Kecamatan Ploso Kabupaten Jombang ada 60 balita. Posyandu balita Dusun Rejoagung Desa Rejoagung Kecamatan Ploso Kabupaten Jombang ketua kader posyandu dan ibu-ibu yang mempunyai motivasi tinggi untuk meningkatkan derajat kesehatan masyarakat khususnya kesehatan balita. Sejak awal berdirinya posyandu balita ini memiliki kader sejumlah 6 yang semuanya terdiri dari ibuibu dan baru mulai tahun 2016 memiliki 2 kader laki-laki seiring dengan di resmikannya posyandu ayah peduli balita oleh ibu ketua tim penggerak PKK Kabupaten Jombang pada awal bulan Mei 2016.
Posyandu ayah peduli di Kabupaten Jombang ini merupakan pelopor. Tidak hanya di Jombang, bahkan posyandu ayah ini adalah satu-satunya dan untuk pertama kalinya di Indonesia. Diharapkan keberadaan posyandu ayah peduli ini semakin terus ditingkatkan hingga menjadi posyandu mandiri untuk turut mewujudkkan generasi emas yang sehat, berahlak karimah, berbudi pekerti yang luhur serta para kader posyandu diharapakan untuk terus berinovasi, mencari terobosan baru guna menghadapi permasalahan yang ada didalam (Dinkes Jombang, 2015).

Partisipasi ayah sangat diperlukan dalam pelaksanaan setiap program kegiatan posyandu ayah peduli balita dalam upaya mencapai program. Pencapaian program posyandu ayah peduli balita dipengaruhi oleh beberapa faktor. Beberapa kondisi yang mendorong ayah turut berpartisipasi dalam program tersebut, misalnya ayah akan berpartisipasi jika mereka merasa kegiatan tersebut penting, kegiatan tersebut dapat memberikan perbedaan dengan kegiatan posyandu yang sebelumnya, kegiatan tersebut dapat memberikan manfaat kepada masyarakat, serta dapat meningkatkan pengetahuan bagi masyarakat. Dengan demikian, diharapkan posyandu ayah peduli dapat mengurangi masalah kesehatan serta meningkatkan kesehatan masyarakat sekitar terutama untuk meningkatkan kesehatan balita. 
KAJIAN LITERATUR

\section{Konsep Posyandu}

Posyandu merupakan salah satu bentuk Upaya Kesehatan Bersumber Daya Masyarakat (UKBM) yang dikelola dan diselenggarakan dari, oleh, untuk, dan bersama masyarakat dalam penyelenggaraan pembangunan kesehatan, guna memberdayakan masyarakat dan memberikan kemudahan kepada masyarakat dalam memperoleh pelayanan kesehatan dasar untuk mempercepat penurunan angka kematian ibu dan bayi. Selain itu, posyandu merupakan bentuk partisipasi masyarakat yang sungguh membawa arti yang sangatbesar bagi kesehatan dan kesejahteraan masyarakat (Pedoman Umum Pengelolaan Posyandu, Depkes RI, 2006). Sasaran dari program Posyandu adalah seluruh masyarakat, terutama bayi, anak balita, ibu hamil, ibu melahirkan, ibu nifas dan ibu menyusui dan Pasangan Usia Subur (PUS).

Waktu penyelenggaraan posyandu pada hakikatnya dilakukan dalam 1 (satu) bulan kegiatan, baik pada hari buka Posyandu, maupun diluar hari buka Posyandu. Hari buka posyandu sekurangkurangnya satu hari dalam sebulan. Dimana hari dan waktu dipilih berdasarkan kesepakatan (Depkes RI, 2006). Adapun kegiatan rutin Posyandu diselenggarakan dan di motori oleh kader posyandu dengan bimbingan teknis dari puskesmas dan sektor terkait. Jumlah minimal kader untuk setiap Posyandu adalah 5 (lima) orang. Jumlah ini sesuai dengan jumlah kegiatan utama yang dilaksanakan oleh Posyandu yaitu langkah pertama pendaftaran, kedua penimbangan, ketiga pengisian KMS, keempat penyuluhan yang dilaksanakan oleh kader, sedangkan langkah kelima adalah pelayanan kesehatan yang dilaksanakan oleh petugas kesehatan dan sektor terkait bersama kader.

Posyandu balita identik dengan tugas kaum perempuan atau ibu yang mengantar anaknya, tetapi pada posyandu ayah peduli ada peran serta para ayah mengantar ke posyandu dan ada kader laki-laki yang turut memberikan pelayanan. Kebersamaan dan kedekatan ayah dan balitanya tampak di posyandu.
Ada seorang ayah yang terlihat menenangkan balitanya yang mulai rewel. Ada juga yang mengajak bermain. Ada seorang ayah yang tengah berbagi minuman kacang hijau dan menyuapinya sambil menunggu antrian. Kepedulian dan keterlibatan para laki-laki di posyandu diharapkan menjadi bentuk kerjasama yang baik antara ayah dan ibu sebagai orang tua dalam memantau tumbuh kembang anak. Sudah menjadi kewajiban para orang tua untuk berbagi peran di dalam membesarkan dan mendidik anakanaknya. Jika suami sibuk, anak bisa diantar oleh ibunya ke posyandu. Apabila istri yang lagi sibuk, anak bisa diantar ayahnya ke posyandu, sehingga ada kerjasama yang baik di dalam memantau tumbuh kembang anak.

\section{Konsep Partisipasi}

Partisipasi adalah keterlibatan masyarakat secara sukarela dalam perubahan yang ditentukan sendiri oleh masyarakat. Partisipasi juga diartikan sebagai keterlibatan masyarakat dalam upaya pembangunan lingkungan, kehidupan, dan diri mereka sendiri (Mikkelsen 2003). Adi (2007) menjelaskan lebih jauh mengenai partisipasi bahwa masyarakat terlibat dalam program pemberdayaan mulai dari proses pengidentifikasian masalah dan potensi yang ada di dalam masyarakat, pemilihan dan pengambilan keputusan tentang alternative solusi untuk menangani masalah, pelaksanaan upaya mengatasi masalah dan keterlibatan masyarakat dalam proses mengevaluasi perubahan yang terjadi. Faktor-faktor yang mempengaruhi partispasi:

a. Jenis kelamin

Partisipasi yang dilakukan oleh seorang laki-laki akan berbeda dengan partisipasi yang dilakukan oleh seorang perempuan. Hal ini disebabkan karena adanya sistem pelapisan sosial yang terbentuk dalam masyarakat yang membedakan kedudukan dan derajat laki-laki dan perempuan, sehingga menimbulkan perbedaan-perbedaan hak dan kewajiban. Pada umumnya kaum laki-laki akan lebih sering 
berpartisipsi dibandingkan dengan kaum perempuan.

b. Tingkat pendidikan

Faktor pendidikan mempengaruhi dalam berpartisipasi karena dengan latar belakang pendidikan yang diperoleh, seseorang akan lebih mudah berkomunikasi dengan orang luar dan cepat tanggap untuk berinovasi dan mempunyai pikiran yang kreatif. Hal ini juga terkait dengan seberapa besar pengetahuan yang dimiliki seseorang dari latar belakang pendidikan yang dimilikinya.

c. Tingkat penghasilan

Tingkat penghasilan seseorang di dalam masyarakat biasanya akan mempengaruhi dirinya dalam berpartisipasi. Jika penghasilan seseorang itu dalam masyarakat besar, maka kemungkinan orang tersebut turut aktif berpartisipasi akan semakin besar pula. Tingkat pendapatan ini mempengaruhi kemampuan untuk melakukan investasi, sehingga bila tingkat penghasilan seseorang dalam masyarakat tersebut rendah maka akan turut mempengaruhi peran sertanya dalam suatu kegiatan atau kata lain tingkat partisipasinya akan cenderung kecil

d. Pekerjaan

Tingkat penghasilan seseorang tentunya berkaitan erat dengan jenis pekerjaan orang tersebut. Jenis pekerjan seseorang akan berpengaruh terhadap banyaknya waktu luang yang dimilikinya dalam turut serta dalam berbagai kegiatan di dalam masyarakat.

e. Usia

Usia juga mempengaruhi seseorang dalam berpartisipasi, hal ini terkait dengan perbedaan kedudukan dan derajat atas dasar senioritas dalam masyarakat, sehingga memunculkan golongan tua dan golongan muda yang berbeda-beda dalam hal tertentu, misalnya menyalurkan pendapat dan mengambil keputusan. Kecenderungan golongan usia yang lebih tua lebih banyak berpartisipasi dibandingkan dengan golongan usia yang lebih muda. f. Lama tinggal

Faktor lama tinggal juga dianggap mempengaruhi seseorang dalam berpartisipasi, dimana seseorang yang lebih lama tinggal dalam suatu masyarakat akan mempunyi perasaan yang lebih besar daripada yang tinggal untuk sementara waktu saja dalam lingkungan masyarakat tersebut.

\section{METODE PENELITIAN}

Jenis penelitian yang digunakan adalah analitik korelasional pendekatan cross sectional. Populasi adalah ayah yang memiliki anak balita di Dusun Rejoagung Desa Rejoagung Kecamatan Ploso Kabupaten Jombang sejumlah 60 ayah. Penelitian dilakukan bulan September 2017. Sampel penelitian ini adalah 53 ayah yang memiliki anak balita di Dusun Rejoagung Desa Rejoagung Kecamatan Ploso Kabupaten Jombang. Pengambilan sampel menggunakan metode probability sampling dengan teknik simple random sampling. Pengumpulan data menggunakan kuesioner dan buku absensi kehadiran posyandu. Analisis data dilakukan pengujian chi square.

\section{HASIL DAN PEMBAHASAN \\ Hasil Penelitian}

Responden dalam penelitian ini berjumlah 53 orang ayah yang memiliki anak balita.

Tabel 1. Distribusi Frekuensi Karakteristik ayah dalam partisipasi posyandu ayah lokasi penelitian

\begin{tabular}{|c|c|c|}
\hline Variabel Penelitian & f & $\%$ \\
\hline \multicolumn{3}{|l|}{ Tingkat pendidikan } \\
\hline SD-SMP & 13 & 24,5 \\
\hline SMU/SMK & 35 & 66 \\
\hline Diploma/Sarjana & 5 & 9,4 \\
\hline Total & 53 & 100 \\
\hline \multicolumn{3}{|l|}{ Penghasilan } \\
\hline < UMK Kabupaten & 40 & 75,5 \\
\hline Jombang 2017 & & \\
\hline$\geq$ UMK Kabupaten & 13 & 24,5 \\
\hline Jombang 2017 & & \\
\hline Total & 53 & 100 \\
\hline \multicolumn{3}{|l|}{ Pekerjaan } \\
\hline PNS & 0 & 0 \\
\hline TNI/POLRI & 1 & 1,9 \\
\hline Swasta & 23 & 43,4 \\
\hline Wirasawasta & 25 & 47,2 \\
\hline Petani/buruh & 4 & 7,5 \\
\hline Total & 53 & 100 \\
\hline
\end{tabular}




\begin{tabular}{ccc}
\hline Usia & 1 & 1,9 \\
$17-25$ & 26 & 49,1 \\
$26-35$ & 26 & 49,1 \\
$36-45$ & $\mathbf{5 3}$ & $\mathbf{1 0 0}$ \\
Total & & \\
Lama tinggal & 16 & 30,2 \\
$\quad$ <5 tahun & 15 & 28,3 \\
5-10 tahun & 22 & 41,5 \\
>15 tahun & $\mathbf{5 3}$ & $\mathbf{1 0 0}$ \\
$\quad$ Total & & \\
Dukungan keluarga & 49 & 92,5 \\
Dukungan baik & 4 & 7,5 \\
Dukungan kurang & $\mathbf{5 3}$ & $\mathbf{1 0 0}$ \\
$\quad$ Total & & \\
Partisipasi & 51 & 96,2 \\
Rendah & 2 & 3,8 \\
Tinggi & 53 & 100 \\
$\quad$ Total &
\end{tabular}

Sumber : Data primer September 2017

Berdasarkan tabel 1 diatas diketahui bahwa karakteristik responden di Dusun Rejoagung Desa Rejoagung mempunyai partisipasi yang rendah yaitu 51 responden $(96,2 \%)$ terhadap kegiatan posyandu ayah peduli. Karakteristik tingkat pendidikan ayah sebagian besar 35 responden $(66 \%)$ berpendidikan sekolah menengah (SMU/SMK). Penghasilan ayah sebagian besar 40 responden $(75,5 \%)$ mempunyai penghasilan di bawah Upah Minimal Regional (UMR) Kabupaten Jombang tahun 2017 sebesar Rp. 2.082.730,00. Pekerjaan ayah hampir setengahnya 25 responden $(47,2 \%)$ sebagai wiraswasta. Usia ayah 26-35 tahun dan 36-45 mempunyai presentasi yang sama yaitu 26 responden $(49,1 \%)$. Lama tinggal ayah di Dusun Rejoagung hampir sebagian $(41,5 \%)$ sudah lebih dari 15 tahun tinggal di Dusun Rejoagung. Hampir semua responden mendapatkan dukungan keluarga baik sebanyak 49 responden $(92,5 \%)$.

Tabel 2. Analisis bivariat Karakteristik ayah dalam partisipasi posyandu ayah di Dusun Rejoagung Desa Rejoagung Kecamatan Ploso Kabupaten Jombang

\begin{tabular}{|c|c|c|c|c|c|c|c|}
\hline \multirow{3}{*}{$\begin{array}{c}\text { Variabel } \\
\text { Independent }\end{array}$} & \multicolumn{6}{|c|}{ Partisipasi Ayah } & \multirow{3}{*}{$\begin{array}{c}\mathrm{P} \\
\text { Value } \\
\end{array}$} \\
\hline & \multicolumn{2}{|c|}{ Rendah } & \multicolumn{2}{|c|}{ Tinggi } & \multicolumn{2}{|c|}{ Total } & \\
\hline & $\mathrm{n}$ & $\%$ & $\mathrm{n}$ & $\%$ & $\mathrm{n}$ & $\%$ & \\
\hline \multicolumn{8}{|l|}{$\begin{array}{l}\text { Tingkat } \\
\text { pendidikan }\end{array}$} \\
\hline SD-SMP & 12 & 92,3 & 1 & 7,7 & 13 & 100 & \multirow{4}{*}{$\begin{array}{c}0,66 \\
1\end{array}$} \\
\hline SMU/SMK & 34 & 97,1 & 1 & 2,9 & 35 & 100 & \\
\hline $\begin{array}{l}\text { Diploma/Sar } \\
\text { jana }\end{array}$ & 5 & 100 & 0 & 0 & 5 & 100 & \\
\hline Total & 51 & 96,2 & 2 & 3,8 & 53 & 100 & \\
\hline
\end{tabular}

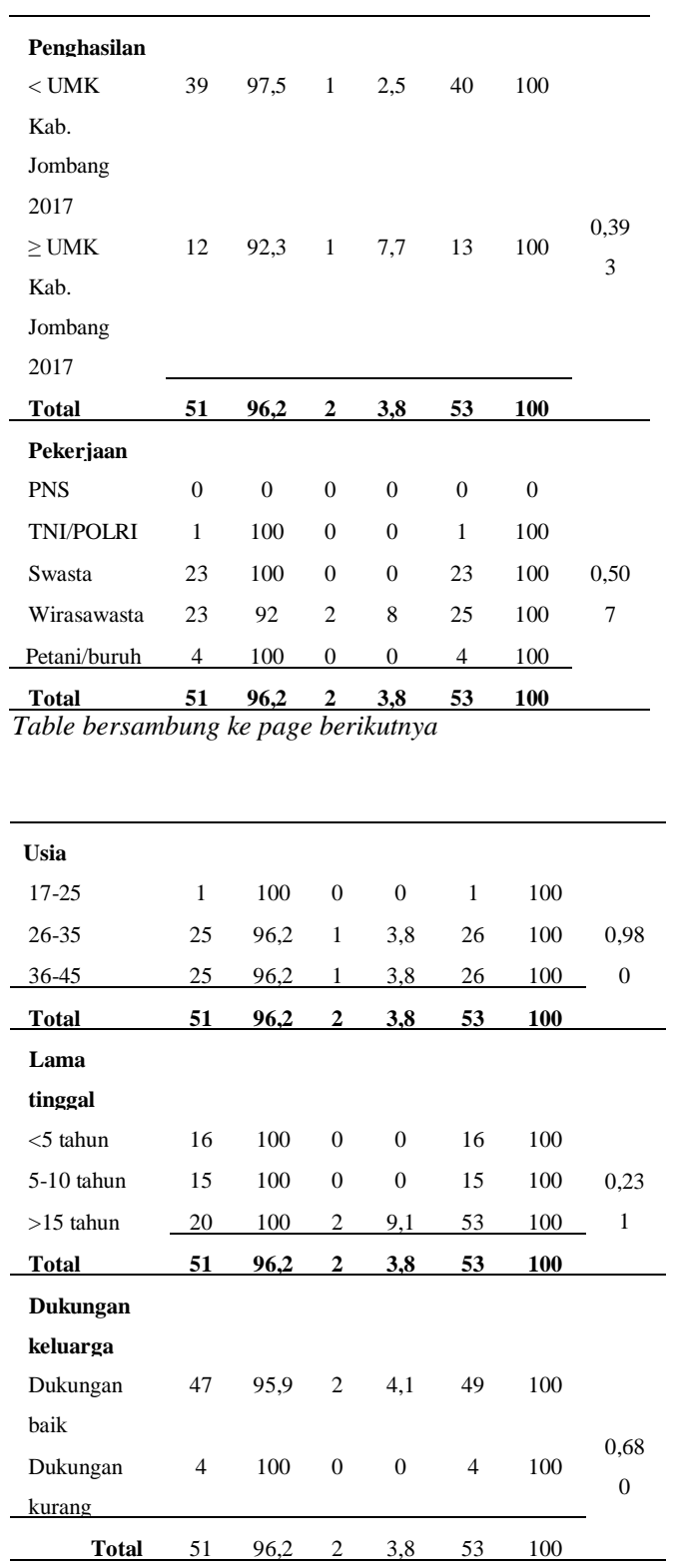

Sumber : data primer September 2017

Berdasarkan tabel 2 di atas dapat diketahui bahwa tidak ada karakteristik ayah baik tingkat pendidikan, penghasilan, pekerjaan, usia, lama tinggal maupun dukungan keluarga yang mempengaruhi partisipasi posyandu ayah di Dusun Rejoagung Desa Rejoagung Kecamatan Ploso Kabupaten Jombang.

\section{PEMBAHASAN}

1. Hubungan antara tingkat pendidikan dengan partisipasi ayah

Berdasarkan tabel 2 dapat diketahui bahwa ayah yang aktif mengantarkan balitanya ke posyandu mempunyai tingkat pendidikan dasar sebanyak $7,7 \%$ dan 
pendidikan menengah 2,9\%. Analisis lebih lanjut didapatkan nilai $\mathrm{p}=0,661$ yang artinya tidak ada hubungan antara tingkat pendidikan ayah dengan partisipasi posyandu ayah peduli ( $\mathrm{p}$ value $>0,05$ ).

Hasil penelitian ini sejalan dengan penelitian yang dilakukan oleh Darmawan (2015) bahwa pendidikan orang tua tidak berhubungan dengan pemanfaatan pelayanan posyandu. Penelitian lain yang sejalan adalah penelitian yang dilakukan oleh Rosyid, dkk (2009) yang bertujuan untuk mengetahui faktor pendidikan terhadap kunjungan lansia ke posyandu lansia. Hasil dari penelitian tersebut diperoleh nilai $\mathrm{p}=0,528$ yang berarti tidak ada hubungan antara pendidikan dengan perilaku kunjungan lansia ke posyandu.

Secara teori dijelaskan bahwa pendidikan diperlukan oleh seseorang untuk mendapatkan informasi, misalnya informasi tentang manfaat posyandu (Wawan dan Dewi, 2010). Selain itu, tingkat pendidikan dapat mempengaruhi pastisipasi dan peran serta masyarakat dalam berperilaku. Seseorang yang menerima pendidikan yang lebih baik atau tinggi, biasanya akan lebih mampu berfikir secara objektif dan rasional. Dengan berfikir secara rasional, maka seseorang akan lebih mudah menerima hal-hal baru yang dianggap menguntungkan bagi dirinya (Notoatmodjo, 2010).

Ketidaksesuaian hasil penelitian ini dengan teori yang ada kemungkinan disebabkan oleh karakteristik responden. Selain itu ketidakbermaknaan antara tingkat pendidikan ayah terhadap partisipasi posyandu ayah peduli dikarenakan pendidikan pada dasarnya tidak hanya dapat diperoleh dari bangku sekolah formal akan tetapi juga di lingkungan keluarga, masyarakat dan media lainnya (majalah, berita).

2. Hubungan antara penghasilan dengan partisipasi ayah

Berdasarkan tabel 2 dapat diketahui bahwa ayah yang aktif mengantarkan balitanya ke posyandu mempunyai penghasilan di bawah UMR sebanyak $2,5 \%$ dan di atas UMR sebanyak 7,7\%.
Analisis lebih lanjut didapatkan nilai $\mathrm{p}=$ 0,393 yang artinya tidak ada hubungan antara tingkat penghasilan ayah dengan partisipasi posyandu ayah peduli ( $\mathrm{p}$ value $>0,05)$.

Status sosial ekonomi menggambarkan tingkat penghidupan seseorang atau keluarga yang ditentukan oleh unsur pendidikan, pekerjaan dan penghasilan. Tingkat penghasilan merupakan faktor sosial ekonomi yang secara tidak langsung akan mempengaruhi partisipasi dalam kegiatan posyandu. Tingkat penghasilan akan menentukan kemampuan untuk memenuhi kebutuhan (Suryaningsih, 2012). Pada penelitian ini faktor penghasilan tidak mempengaruhi keaktifan ayah di posyandu karena masyarakat berpendapat siapa yang mempunyai waktu luang lebih banyak dapat mengantarkan anaknya ke posyandu. Jika istri sedang sibuk atau berhalangan, ayah dapat mengantarkan anaknya ke posyandu.

3. Hubungan antara pekerjaan dengan partisipasi ayah

Berdasarkan tabel 2 dapat diketahui bahwa ayah yang aktif mengantarkan balitanya ke posyandu mempunyai pekerjaan sebagai wirasawasta sebanyak $8 \%$. Analisis lebih lanjut didapatkan nilai $\mathrm{p}=0,507$ yang artinya tidak ada hubungan antara pekerjaan ayah dengan partisipasi posyandu ayah peduli ( $\mathrm{p}$ value $>$ 0,05). Hasil penelitian ini sejalan dengan penelitian yang dilakukan oleh Darmawan (2015) bahwa pekerjaan tidak berhubungan dengan pemanfaatan pelayanan posyandu. Hasil dari penelitian ini diperoleh nilai $\mathrm{p}=0,964$. Pekerjaan wiraswasta memungkinkan seseorang mempunyai waktu luang yang lebih banyak dan tidak mempunyai keterikatan waktu dengan pekerjaan sehingga memungkinkan seorang ayah dapat mengantarkan anaknya ke posyandu.

4. Hubungan antara usia dengan partisipasi ayah

Berdasarkan tabel 2 dapat diketahui bahwa ayah yang aktif mengantarkan balitanya ke posyandu mempunyai usia 26-35 dan 36-45 masing-masing 3,8\%. 
Analisis lebih lanjut didapatkan nilai $\mathrm{p}=$ 0,980 yang artinya tidak ada hubungan antara usia ayah dengan partisipasi posyandu ayah peduli ( $\mathrm{p}$ value $>0,05$ ) Hasil penelitian ini sejalan dengan penelitian yang dilakukan oleh Darmawan (2015) bahwa usia ayah tidak berhubungan dengan pemanfaatan pelayanan posyandu. Hasil yang sama juga dari penelitian Suryaningsih (2012) terhadap ibu bayi dan balita sebanyak 242 responden. Hasil dari penelitian ini diperoleh nilai $p=0,267$ artinya tidak ada hubungan antara usia dengan perilaku kunjungan ibu ke posyandu ( $\mathrm{p}>0,05)$. Dalam penelitian ini juga menjelaskan bahwa usia ayah hanya merupakan suatu karakteristik individu dan merupakan faktor demografis yang menjadi faktor predisposisi saja, sedangkan kunjungan ke posyandu merupakan suatu bentuk perilaku kesehatan khususnya berhubungan dengan pemanfaatan pelayanan kesehatan. Sedangkan secara teori menjelaskan bahwa pada umumnya seseorang yang berumur lebih tua akan lebih bertanggungjawab dan lebih teliti dalam segala hal dibandingkan dengan seseorang yang berusia lebih muda. Hal ini terjadi dikarenakan usia yang lebih tua telah berpengalaman dan umumnya telah mampu mengambil keputusan (Notoadmodjo, 2010). Selain itu menurut Ekasari (2008) menjelaskan bahwa seiring dengan bertambahnya usia seseorang, menyebabkan terjadi peningkatan kebutuhan akan pelayanan khusus yang berbasis masyarakat.

5. Hubungan antara lama tinggal dengan partisipasi ayah

Berdasarkan tabel 2 dapat diketahui bahwa ayah yang aktif mengantarkan balitanya ke posyandu bertempat tinggal lebih dari 15 tahun di Dusun Rejoagung sebanyak 9,1\%. Analisis lebih lanjut didapatkan nilai $\mathrm{p}=0,231$ yang artinya tidak ada hubungan antara lama tinggal ayah dengan partisipasi posyandu ayah peduli ( $\mathrm{p}$ value $>0,05$ ). Faktor lama tinggal dianggap mempengaruhi seseorang dalam berpartisipasi, dimana seseorang yang lebih lama tinggal dalam suatu masyarakat akan mempunyi perasaan yang lebih besar daripada yang tinggal untuk sementara waktu saja dalam lingkungan masyarakat tersebut (Slamet, 1994). Lama tinggal tidak berpengaruh dalam menentukan partisipasi karena setiap orang mempunyai kegiatan dan kesibukan yang berbeda-beda yang tidak ditentukan oleh lama/tidaknya sudah bertempat tinggal di suatu daerah.

6. Hubungan antara dukungan keluarga dengan partisipasi ayah

Hasil analisis didapatkan nilai $\mathrm{p}=$ 0,680 yang artinya tidak ada hubungan antara dukungan keluarga dengan partisipasi posyandu ayah peduli ( $\mathrm{p}$ value $>$ 0,05). Menurut teori Green (2005) bahwa faktor penguat untuk seseorang berperilaku sehat yaitu berdasarkan dukungan keluarga. Partisipasi ayah yang membawa balitanya maupun suami yang mendampingi istrinya ke posyandu setiap bulan merupakan upaya untuk meningkatkan pelayanan kesehatan karena kepedulian dan keterlibatan ayah menjadi sebuah bentuk kerjasama yang baik antara ayah dan ibu sebagai orang tua didalam memantau tumbuh kembang anak.

Partisipasi ayah yang aktif membawa anaknya setiap bulan ke posyandu akan mendukung program posyandu untuk mencapai tingkat derajat yang maksimal bagi kesehatan balita. Derajat kesehatan balita tidak terlepas dari peran orang tua baik ibu maupun ayah, yang memiliki kewajiban untuk senantiasa memberikan perhatian bagi kesehatan balita mereka. Untuk menjaga kesehatan balita, sebagai orang tua baik ibu maupun ayah akan melakukan berbagai upaya seperti menjaga kualitas makanan yang dikonsumsi balita serta membawa balita mereka ke posyandu sehingga kesehatan balita mereka dapat dipantau secara maksimal, baik berat badan, panjang badan/tinggi badan, status gizi serta imunisasi yang diberikan. Dari berbagai macam bentuk partisipasi ayah dalam posyandu ayah peduli balita, terdapat beberapa faktor yang mempengaruhi partisipasi para orang tua terutama ayah balita dan kader laki-laki dalam upaya pelayanan kesehatan balita di posyandu balita. Faktor-faktor tersebut dibagi menjadi dua yaitu faktor internal dan faktor eksternal. 
Faktor internal dapat dilihat dari adanya pengetahuan yang baik tentang pentingnya kesehatan dan pemahaman pentingnya balita memiliki kesehatan yang baik. Keadaan ini mendorong mereka untuk berpartisipasi dan datang untuk memanfaatkan pelayanan posyandu. Begitu pula faktor lama tinggal, usia, kebiasaan serta pekerjaan yang mayoritas tani, wirausaha dan pedagang memudahkan mereka untuk berpartisipasi dalam pelayanan kesehatan balita di posyandu.

Adapun faktor eksternal yang mempengaruhi adalah adanya dukungan dari keluarga (istri), orang tua, dukungan kader posyandu serta adanya kemudahan mencapai lokasi posyandu, dimana letak posyandu relatif dekat dengan rumah, yang bisa dicapai dengan berjalan kaki. Dalam hal berorganisasi para partisipan mayoritas tidak mempunyai pengalaman organisasi tetapi tetap berpartisipasi dalam pelayanan posyandu balita.

Tidak adanya penghargaan dari orang lain tidak menyurutkan partisipan untuk berpartisipasi dalam pelayanan kesehatan balita di posyandu, yang rutin memanfaatkan pelayanan posyandu. Hal tersebut terutama didorong oleh keinginan yang kuat untuk mengetahui pertumbuhan dan perkembangan balitanya. Ayah mendapatkan manfaat dari keikutsertaan di posyandu. Adanya dukungan keluarga membuat para partisipan tetap percaya diri ketika berpartisipasi dalam pelayanan kesehatan dengan membawa balitanya ke posyandu. Menurut partisipan dari faktorfaktor yang mempengaruhi mereka membawa anaknya ke Posyandu tidak terlepas dari dukungan keluarga

\section{KESIMPULAN DAN SARAN}

Berdasarkan hasil penelitian dan pembahasan yang telah diuraikan sebelumnya maka dapat ditarik kesimpulan bahwa:

1. Tidak ada hubungan antara tingkat pendidikan ayah dengan partisipasi posyandu ayah peduli di Dusun Rejoagung Desa Rejoagung Kecamatan Ploso Kabupaten Jombang

2. Tidak ada hubungan antara penghasilan ayah dengan partisipasi posyandu ayah peduli di Dusun Rejoagung Desa Rejoagung Kecamatan Ploso Kabupaten Jombang

3. Tidak ada hubungan antara pekerjaan ayah dengan partisipasi posyandu ayah peduli di Dusun Rejoagung Desa Rejoagung Kecamatan Ploso Kabupaten Jombang

4. Tidak ada hubungan antara usia ayah dengan partisipasi posyandu ayah peduli di Dusun Rejoagung Desa Rejoagung Kecamatan Ploso Kabupaten Jombang

5. Tidak ada hubungan antara lama tinggal ayah dengan partisipasi posyandu ayah peduli di Dusun Rejoagung Desa Rejoagung Kecamatan Ploso Kabupaten Jombang

6. Tidak ada hubungan antara dukungan keluarga dengan partisipasi posyandu ayah peduli di Dusun Rejoagung Desa Rejoagung Kecamatan Ploso Kabupaten Jombang

\section{DAFTAR PUSTAKA}

Adi, Isbandi Rukminto. (2007). Perencanaan Partisipatoris Berbasis Aset Komunitas Dari Pemikiran Menuju Penerapan (Seri Pemberdayaan Masyarakat 04). Jakarta: FISIP UI Press.

Darmawan, N.K (2014). Faktor-faktor yang mempengaruhi perilaku kunjungan masyarakat terhadap pelayanan posyandu di desa Pemecutan Kelod Kecamatan Denpasar Barat. Jurnal Dunia Kesehatan Volume 5 NO. 2

Departemen Kesehatan RI, (2006). Pedoman Umum Pengelolaan Posyandu. Jakarta : Departemen Kesehatan RI

Departemen Kesehatan RI, (2009). Pedoman Umum Pengelolaan Posyandu. Jakarta : Departemen Kesehatan RI

Dinas Kesehatan Kabupaten Jombang. (2015). Posyandu Ayah Peduli Balita. Jombang: Dinkes Kab. Jombang.

Ekasari, F.M (2008). Keperawatan Komunitas. Jakarta : Trans Info Medika.

Green, LW. And Kreuter, M. W. 2005. Health Program Planning: An Educational and Ecological Approach. 
4th edition. Ny: McGraw-Hill Higher Education

Mikkelsen, B. (2001). Metode penelitian partisipatoris dan upaya-upaya pemberdayaan. Alih bahasa Nalle Matheos. Jakrta: Yayasan Obor Indonesia

Notoadmodjo. (2012). Metodologi Penelitian Kesehatan. Jakrta: Rineka Cipta

Rosyid, dkk. (2010). Faktor-faktor yang mempengaruhi kunjungan lansia ke posyandu lansia di RW VII Kelurahan Wonokusumo Kecamatan Semampir Surabaya. Journal from UM Surabaya. Volume 5 No. 1

Slamet. (1994). Pembangunan Masyarakat Berwawasan Partisipatif. Surabaya: Trans Info Medika

Suryaningsih, Hesti. (2012). Faktor-faktor yang berhubungan dengan perilaku kunjungan ibu bayi dan balita ke posyandu di puskesmas Kemiri Muka Kota Depok. Skripsi Program Studi Kesehatan Masyarakat Universitas Indonesia.

Wawan dan Dewi. (2011). Teori dan pengukuran pengetahuan, sikap dan perilaku. Cetakan II. Yogyakarta: Nuha Medika 